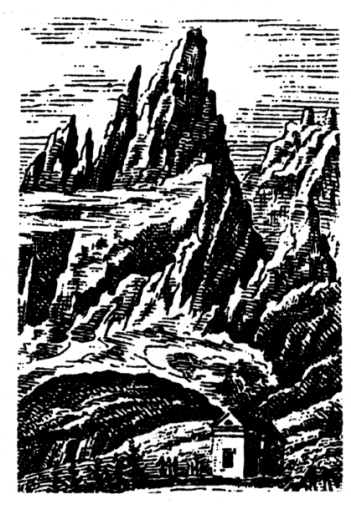

\title{
Renata Gadamska-Serafin
}

Uniwersytet Jagielloński

renia5555@wp.pl

\section{Góry Kaukaz jako wrota Orientu. Motywy orientalne w twórczości Tadeusza Łady-Zabłockiego}

Słowa-klucze: góry, Kaukaz, Orient, poezja

Keywords: mountains, Caucasus, Orient, poetry

\section{The Caucasus as a gate to the Orient. Oriental motifs in Tadeusz Łada-Zabłocki's oeuvre}

\section{Summary}

The East, its culture and literature were always part of the rich, erudite poetic imagination of Tadeusz Łada-Zabłocki (1811-1847), a tsarist exile to the Caucasus. He spoke Oriental languages (Georgian and Persian) and had a thorough knowledge of the Koran, a short fragment of which he even translated (probably from French). Although today we only have his poetry inspired by the Caucasian mountains, he was also no stranger to extensive travel accounts (unfortunately, his Dziennik podróży mojej do Tyflisu i z Tyflisu po różnych krajach za Kaukazem (Journal From My Journey To and From Tiflis Across Various Countries Beyond the Caucasus) and notes from his Armenian expedition were lost). 
An important source of inspiration for Zabłocki, encouraging him to explore the East, were the Philomaths' translations of Oriental poetry by Jan Wiernikowski and Aleksander Chodźko, while his model of reception of the Orient were the oeuvres of Mickiewicz (primarily his Crimean and Odessa Sonnets), Byron and Thomas Moore (especially the fragment of Lalla Rookh - Paradise and the Peri). The exile brutally brought Zabłocki into contact with the real Orient, terribly dangerous and diametrically different from the one described by Western travellers. It is, therefore, not surprising, that their superficial and simplified accounts were criticised by the Polish poet and soldier.

Zabłocki's oeuvre, both pre-exile and Caucasus period works, is full of various Oriental reminiscences: from the Biblical topos of the Paradise $a b$ Oriente, through numerous splendid images of Caucasian nature, scenes from the life of Caucasian highlanders, poetic imitation of the metre of Caucasian folk dances, apt ethnographic observations in the verses, borrowings from Oriental languages, extraordinarily sensual eastern erotic poems, to translations of texts of Caucasian cultures (Tatar, Azeri and Georgian songs). Zabłocki drew on both folk culture of Caucasian tribes, and on Eastern mythologies as well as universal culture of the Islamic world. $\mathrm{He}$ presents an ambivalent image of Caucasian highlanders in his poetry: sometimes they acquire traits of noble, free, valiant and indomitable individuals, typical of the Romantic idea of highlanders, on other occasions the label "Son of the East" becomes a synonym of Asian barbarity.

Freed from the service in the tsarist army, Zabłocki planned travels across nearby Persia, Asia Minor, and even Arabia, Nubia and Palestine. However, the plans never became a reality, owing to a lack of funds and the poet's early death of cholera.

Zabłocki's "Eastern" oeuvre fully reveals the "liminal", demarcational nature of the Caucasian mountains, for centuries constituting the limes between Europe and Asia, the East and the West, a meeting place of the Christian and the Muslim Orients.

„Romantyczna wyobraźnia dostrzegała, że przestrzenie górskie zakreślają terytorium, na którym krzyżują się rozmaite granice"". Prawda ta urasta do „potęgi drugiej” w odniesieniu do gór rozdzielających dwie odmienne formacje cywilizacyjno-kulturowe: Okcydent i Orient. ,[...] my, ludzie Kaukazu, żyjemy życiem dwu półglobów"2 - pisał Władysław Strzelnicki, sugestywnie oddając rozpięcie tej krainy między Południem i Północą, Wschodem i Zachodem, jej usytuowanie na przecięciu ważnych osi globu: wertykalnej i horyzontalnej. Na Kaukazie stykały się z sobą Oriens christianus (reprezentowany przez Gruzinów, Ormian, większość Osetyńców, a także obecnych na tych ziemiach napływowych Rusinów, Kozaków i Moskali) oraz Oriens islamicus, którego przedstawicielami były rozliczne muzułmańskie plemiona północnokaukaskie (Czerkiesi, część Osetyńców, Czeczeńcy, Lezgini, Tatarzy i Kałmucy itd.), a także zapuszczający się tu Turcy i Persowie. W sensie geograficznym Kaukaz tworzył także limes Europy i Azji. Przez wieki pozostawał końcem, krańcem i rubieżą (dla Zachodu

${ }^{1}$ E. Grzęda, Góry jako granica - ujęcie romantyczne, „Góry — Literatura - Kultura” 1, 1996, s. 30.

2 W. Strzelnicki, List do Jana Załęskiego z 11 lipca 1844, [w:] idem, Szkice Kaukazu, http://kaukaz.upjp2.edu.pl/ksiegozbior_1/szkice_kaukazu_wladyslaw_strzelnicki.html (dostęp: 6.11.2016). Strzelnicki zwracał wszakże ưwagę swego adresata na fakt, iż życie ,życiem dwu półglobów” możliwe jest na Kaukazie tylko dzięki napływającym tu zewsząd dziennikom, które uzmysławiają pozostającym w izolacji wygnańcom, „co stanowi życie moralne, oświatę, postęp”-ibidem.

Góry, Literatura, Kultura 11, 2018

(C) for this edition by CNS 
i Północy), a zarazem bramą, progiem i początkiem (Wschodu), niemal zawsze zaś gorącą linią politycznego podziału i miejscem nieustannych konfliktów.

Kaukaz - pisał Mateusz Gralewski — będąc progiem między Azją i Europą, zawsze stanowił obiekt uwagi i zainteresowania najpotężniejszych na świecie państw. Każde mocarstwo i cywilizacja dążyły do zawładnięcia nim, co miało być ukoronowaniem ich świetności. Następnie zaś słabły i opuszczały Kaukaz, oddając te ziemie własnemu ich losowi albo w ręce silniejszego rywala ${ }^{3}$.

Graniczność Kaukazu miała więc wiele znaczeń: fizyczno-geograficzne, cywilizacyjne, religijne, polityczno-strategiczne, psychologiczne. Dla polskich zesłańców przestrzeń tych gór stawała się inną, tragiczną linią demarkacyjną: kresem wolności, progiem osobistego piekła, wymagającym przekraczania psychicznych i fizycznych granic człowieczeństwa. ,Jakże okrutnie los strawestował w ich życiu — pisał Wacław Kubacki - romantyczną modę wędrówek i krajobrazowych kontemplacji’”. Jakże ironicznie obsadził ich w roli romantycznych wojażerów do czarującego magią odmienności i najstarszymi ,archiwami Ludzkości”5 Orientu.

Materiał dotyczący kaukaskiego Wschodu, zapisany w zesłańczej twórczości dziewiętnastowiecznej (w poezji, pamiętnikach, prozie), jest obszerny i do dziś nieprzebadany gruntownie. Tymczasem kryje on w sobie wielkie bogactwo, zarówno literackie, jak i kulturowe (muzyka i taniec ludów kaukaskich, folklor, historia, religie, obyczaje, stroje, święta itd.). Zasługuje na rzetelne naukowe opracowanie przede wszystkim dlatego, że jest to w dziejach orientalizmu europejskiego rozdział zupełnie odrębny, bezprecedensowy, pisany nie z typowej dla ówczesnego Zachodu perspektywy kolonialnej — pozycji dominacji i ekonomicznego interesu (odsądzonej od prawdy i wartości przez Edwarda Saida); nie przez ludzi, dla których Orient stanowił wrota do kariery, lecz przez odartych z praw więźniów politycznych, którzy dotykali niezwykle realnej, bolesnej strony bytu. Zesłańcami byli częstokroć ludzie gruntownie wykształceni, studenci prestiżowych uczelni, intelektualiści, literaci, inżynierowie, erudyci mający świetne przygotowanie badawcze i intelektualne narzędzia pozwalające na adekwatny opis otaczającej ich rzeczywistości. Nic dziwnego, że polscy Kaukazczycy niejednokrotnie przewracali do góry nogami zmityzowane wizje Orientu wykre-

3 M. Gralewski, Kaukaz. Wspomnienia z dwunastoletniej niewoli, oprac. P. Adamczewski, Poznań 2015, s. 17, http://www.dbc.wroc.pl/dlibra/docmetadata?id=7411\&from=publication (dostęp: 6.11.2016).

${ }^{4}$ W. Kubacki, Malwy na Kaukazie, Warszawa 1969, s. 68.

5 O owych wschodnich ,archiwach Ludzkości”, „całą PRZESZŁOŚĆ człowieka obchodzących", pisał w 1877 r. w liście do Bronisława Zaleskiego Cyprian Norwid (zob. idem, Pisma wszystkie, oprac. J.W. Gomulicki, Warszawa 1971, t. 10. Listy, s. 107-108). Autor listu trafnie zauważy1, że w drugiej połowie XIX stulecia owo „muzeum pomników pierwotnych” „w większej części" trafiło pod panowanie Rosji w wyniku jej brutalnej ekspansji na zachód oraz południe. W granicach Cesarstwa Rosyjskiego znalazło się m.in. historyczne terytorium Armenii i znaczne obszary Kaukazu. 
owane przez zachodnioeuropejskich podróżników, których relacje znali przecież świetnie ze studiów i lektur. Nicowali je, poddawali ironicznej weryfikacji, polemizowali z nimi 6 , wreszcie zastępowali rzetelniejszymi opisami. Choć obrazy kaukaskiego Wschodu są w polskiej twórczości zesłańczej różnorodne, to jednak ich cechą wspólną jest to, że na ogół odbiegają od owych ustereotypizowanych klisz na rzecz ujęć etnograficznych, naukowych (z naciskiem na prawdę, dane historyczne, geograficzne itp.), realistycznych, odmitologizowujących, niekiedy wręcz werystycznych, z gorzką dominantą ironiczno-sarkastyczną?.

Takie są na przykład wizerunki Kaukazu w twórczości Strzelnickiego, który chyba najmocniej przeciwstawił się „orientalnemu snobizmowi swej epoki”, kwestionując go z powodu jego wątpliwej merytoryczności:

Nasze opaczne pojęcia o Wschodzie pochodzą najwięcej stąd, że podróżnicy nasi dobrowolnie poddają się złudzeniom optycznym, biorąc cząstkę jakąś, dach, krużganek kolumnadę, albo i jedną cegiełkę, za cały budynek. Byleby ktoś koniec nosa wetknął w granice Azji, już się ma za biegłego orientalistę, — zaraz wydaje książkę i z jakąż akademiczną przesadą wyrokuje o tym Wschodzie! Niebo wschodnie, gościnność wschodnia, obyczaje wschodnie, powtarzają się na każdej stronicy. Panowie! Panowie! trochę więcej skromności i dobrej wiary! Spójrzcie na mapę! oto macie przed sobą 800000 mil kwadratowych przestrzeni, nie licząc Egiptu i brzegów Barbaryjskich, które także do Wschodu zwykliście odnosić. - A jeszczeż kraje, rozrzucone po tej ogromnej przestrzeni, nierównie więcej różnią się między sobą, tak co do nieba, ziemi, jak co do ludzi, niż kraje waszego Jafetowego mrowiska. O! panowie! żeby ten Wschód objąć i zrozumieć, trzeba czegoś więcej niż zjeść kilka

${ }^{6}$ Przedmiotem polemik pozostawało m.in. współczesne dzieło A. Dumasa Kaukaz. Od Prometeusza do Szamila (dyskusję z wizją Dumasa podjęli np. Henryk Dzierżek i Jakub Gordon). Zob. W. Kubacki, op. cit., s. 410.

${ }^{7}$ Bardzo celnie zrekapitulował charakter polskiej literatury kaukaskiej W. Kubacki: „Polscy pisarze rozwiewali orientalne mity epoki, zestawiając romantyczne wyobrażenia z gospodarczą i społeczną rzeczywistością" - idem, op. cit., s. 410. Badająca Szkice Kaukazu Władysława Strzelnickiego Elżbieta Lijewska doszła do podobnych konkluzji: ,»Kaukazczycy« zmuszeni do wisielczo-romantycznej podróży na Wschód weryfikowali swoje dotychczasowe, ukształtowane na literaturze europejskiej, wyobrażenia. Czasem przyjmowali postawę wyższości nad ową „komedią ludzką" o gorzkim posmaku, stąd sarkazm w ich literackich utworach. [...] Oscylowanie między podróżowaniem a tułactwem, charakterystyczne dla podróżopisarstwa kaukaskiego, ujawnia się szczególnie u Strzelnickiego. Pisarz, deheroizując obraz Wschodu, wydobywa to, co śmieszne, zwykłe, poniżone, kwestionuje nawet egzotyzm tego świata. [...] Wymuszona podróż na Wschód, na Kaukaz, wyzwoliła nową, śmiałą panoramę rzeczywistości, usianej barwnym kwieciem i pokrzywami” — eadem, ,, Szkice kaukaskie”. O twórczości wygnańczej Władysława Strzelnickiego, Poznań 1998, s. $149-150$.

8 W. Kubacki, op. cit., s. 405.

Góry, Literatura, Kultura 11, 2018

(C) for this edition by CNS 
obiadów i odprawić kilka mszy w klasztorach Palestyny, albo piastować przez kilka lat urząd konowała na dworze Mehmed-Alego9.

Osobny rozdział w tym wielkim i ciekawym zagadnieniu orientalnym formuje twórczość Tadeusza Łady-Zabłockiego, który — podobnie jak jego przyjaciel Strzelnicki — pisał o Kaukazie kompetentnie, gdyż po pierwsze władał językami Orientu (gruzińskim i perskim ${ }^{10}$ ), po drugie znał gruntownie Koran ${ }^{11}$.

Jak podkreśliła Danuta Ossowska, Poezje Zabłockiego, wydane w 1845 r. przez Romualda Podbereskiego, były pierwszą w latach międzypowstaniowych zwartą publikacją, która wprowadzała temat kaukaski do życia literackiego ${ }^{12}$. Do dziś ocalał jedynie poetycki zapis kaukaskich doświadczeń Zabłockiego, ale nieobca była też temu pisarzowi forma rozbudowanej relacji podróżniczej. Niestety, przepadł jego trzyczęściowy Dziennik podróży mojej do Tyflisu i z Tyflisu po różnych krajach za Kaukazem, przekazany Ignacemu Ciechanowieckiemu (z nadzieją wydania go $\mathrm{w}$ Lipsku ${ }^{13}$ ), którą to relację poeta miał zamiar jeszcze skorygować i uzupełnić o wrażenia oraz spostrzeżenia $\mathrm{z}$ lat późniejszych ${ }^{14}$. List do Józefa Ignacego Kraszewskiego z 3 marca 1841 r. pozwala przypuszczać, że byłoby to dziś niezwykle cenne, pełne impresji świadectwo zetknięcia pisarza z kaukaskimi górami i rozciągającym się za nimi Orientem:

Nie mogę teraz przywołać sobie na pamięć tych wrażeń, którem odebrał na widok cudów Kaukazu. - Dusza moja, przygotowana czteroletnim odosobnieniem od świata i ludzi, była daleko czulszą, pojętniejszą, inaczej zazwyczaj musiała czuć i pojmować, i cudniejsze barwy narzucać na otaczające ją przedmioty. - Pomnę tylko, że kilka razy płakałem $\mathrm{z}$ uniesienia, i w temże samym miejscu na stepach, nad brzegami rzek i u stóp gór podniebnych, nie dając czasu ostygnąć natchnieniu, rzuca-

9 W. Strzelnicki, Szkice Kaukazu, Żytomierz 1860, s. 13, http://kaukaz.upjp2.edu.pl/ksiegozbior_1/szkice_kaukazu_wladyslaw_strzelnicki.html (dostęp: 27.03.2017). Własne, oryginalne podejście do tematyki Wschodu i islamu Strzelnicki zaprezentował w dwóch powieściach kaukaskich: Dwaj Uzdeni (Żytomierz 1860) i Mahmudek („Biblioteka Warszawska” 1-2, 1847 oraz wyd. osobne: Żytomierz 1860). Zob. też E. Lijewska, Kaukaz - Wschód czy Azja, [w:] eadem, Szkice kaukaskie”..., s. 136-150.

10 O swej znajomości języków Wschodu pisał Zabłocki w listach do Kraszewskiego.

11 O znajomości Koranu świadczy przede wszystkim jego tłumaczenie fragmentu jednej z sur, o czym będzie jeszcze mowa w dalszej części niniejszej publikacji.

12 Zob. D. Ossowska, Tadeusz Łada-Zabłocki - poeta kaukaski, [w:] Poezje Tadeusza Łady-Zabłockiego, oprac. W. Gącerz, G. Gilewski, Kraków 2013, http://kaukaz.upjp2.edu.pl/ksiegozbior_1/poezje_tadeusz_lada_zablocki.html (dostęp: 27.03.2017).

${ }_{13}$ Zob. List T. Lady Zabłockiego do J.I. Kraszewskiego z 16 XI 1840 roku, [w:] M. Filina, D. Ossowska, Losy Polaków na Kaukazie, cz. I. „,Tbiliska grupa” polskich poetów zestańczych, Tbilisi 2007, s. 228.

${ }^{14}$ Starania Kraszewskiego o odzyskanie tego rękopisu od Ciechanowieckiego spełzły niestety na niczym. 
łem na papier zarysy, obrazy i ówczesne wrażenia moje. Wielka szkoda, że [...] nie zostawiłem dla siebie kopii ${ }^{15}$.

Z kolei w liście do Podbereskiego z 1843 r. znajdziemy wzmiankę o notatkach sporządzonych z myślą o literackim opisie innej wschodniej wyprawy armeńskiej:

[...] korzystałem przed dwoma miesiącami ze szczęśliwej okoliczności i zwiedziłem jeszcze przez nikogo z naszych nie zwiedzaną Armenię Wielką. Byłem w Erywanie, Nachiczywanie, Ordubacie, Eczmiadzynie, na Araracie, w Irdyrze itd. Słowem wzdłuż po granicy Persji i Turcji. Wrażenia z tej podróży, zanotowane w pugilaresie, dotąd leżą in crudo ${ }^{16}$.

Przymuszony do udziału w kolejnej ekspedycji wojennej, Zabłocki nie był w stanie uczynić zadość prośbie Kraszewskiego o nadesłanie ,jakichkolwiek widoków Kaukazu, scen miejscowych, strojów tutejszych itd."17 Nosił się natomiast z zamiarem posłania mu swej rozprawy o poezji gruzińskiej - Rzut oka na piśmiennictwo gruzyjskie ${ }^{18}$.

W liście do tegoż samego adresata z roku 1847 Zabłocki wytknął wiele błędów i zafałszowań zachodnim relacjom z Kaukazu, podkreślając zarazem profesjonalizm i wyższość kaukaskich szkiców polskich, zwłaszcza swego przyjaciela Strzelnickiego:

Niech Pan nie wierzy w opisania podróży po Kaukazie Francuzów i Niemców. Dubois du Montepereux ${ }^{19}$ dużo kłamstw puścił w obieg,

15 Zob. List T. Łady Zabłockiego do J.I. Kraszewskiego z 3 III 1841 roku, [w:] M. Filina, D. Ossowska, op. cit., s. 232.

16 T. Łada-Zabłocki, List do R. Podbereskiego z 10 VI 1843 roku, [w:] M. Filina, D. Ossowska, op. cit., s. 254.

${ }^{17}$ Ibidem. Na prośbę Zabłockiego, zrobić to miał porucznik Lachowicz, który jednak wyjechał na Litwę i w końcu żadnych materiałów Kraszewskiemu nie przekazał. W tym samym liście Zabłocki zawiadamiał Kraszewskiego o thumaczeniu przez księcia Erystawi Sonetów krymskich Mickiewicza na gruziński oraz Farysa na język perski (przez anonimowego thumacza).

18 Zob. List T. Łady Zabłockiego do J.I. Kraszewskiego z 21 VI 1842 roku, [w:] M. Filina, D. Ossowska, op. cit., s. 238. Z listów wynika, że Zabłocki wspierał też pomysłami Michała Butowta Andrzejowicza w trakcie pisania przez niego Szkiców Kaukazu: „Radzisz mi Pan zająć się opisem wędrówek moich po Kaukazie. Rzecz pewna, że należałoby się wstydzić za ziomków naszych, gdy żaden z nich, którzy byli lub się obecnie znajdują na Kaukazie, nie zajął się traktowaniem tego przedmiotu tyle ważnego i tyle nas interesującego. Brak zdrowia i czasu nie pozwalają mi poświęcić się temu, lecz wrażenia i postrzeżenia moje komunikuję Panu Michałowi Butowtowi, który od kilku lat pracuje nad opisaniem Kaukazu, uczy się języków tutejszych, zbiera historyczne materiały i już znaczną część tego pisma tyle ważnego i ciekawego dla nas, wykończył". Zob. List T. Łady Zabłockiego do J.I. Kraszewskiego z 5 I 1843 roku, [w:] M. Filina, D. Ossowska, op. cit., s. 240. Zabłocki wspominał też Kraszewskiemu o przygotowywanych Wrażeniach z podroży odbytej na Kaukaz Leona Janiszewskiego - ibidem, s. 241.

19 Mowa o Frédéricu Dubois de Montpéreux (1798-1850), pisarzu, historyku i archeologu, który wydał Voyage autour du Caucase, chez les Tscherkesses et les Abkhases, en Colchide, en Géorgie, en Arménie et en Crimée, 6 tomów, Paris 1839-1849 (wyd. niemieckie: Reise um den

Góry, Literatura, Kultura 11, 2018

(C) for this edition by CNS 
chociaż jest jednym z najuczciwszych podróżopisarzy. Co on mówi o podobieństwie Abchazów z Litwinami, wierutne kłamstwo. Ossetyni rzeczywiście mają oczy błękitne i włos światły i tymi słowiańskimi cechami odznaczają się od wszystkich ludów kaukaskich, lecz w ich języku nie ma jednego wyrazu słowiańskiego; mają kilka słów niemieckich, a między innymi ,werden" i, ,haben” skąd by się wzięło, nieodgadniona tajemnica. Aby Kaukaz wyśledzić pod względem etymologicznym, trzeba mieć zdolności Mezzofanti ${ }^{20}$. Bo oprócz trzech głównych języków armeńskiego, tatarskiego i gruzyjskiego zupełnie odrębnych od siebie, znajdują się język abchaski, czerkieski, ossetyński, lezgiński, awarski, kumuchski, purdzki itp. składające oddzielne szczepy. Nieodżałowana szkoda Strzelnickiego. On znał tatarski i lezgiński język, zaczął się uczyć kumuchskiego i wielkie, wielkie światło rzuciłby na Kaukaz, tym bardziej, że Książę Namiestnik wybrał jego do badania Kaukazu²1.

O otwarciu się Zabłockiego na tematykę orientalną zdecydowała bez wątpienia jego ogromna erudycja (ale i ,bliskość” orientalnych przekładów filomackich!), zauważona przez wszystkich edytorów i znawców jego twórczości (Józef Ignacy Kraszewski, Maria Janion, Danuta Ossowska), wpływająca na charakterystyczną, ,wieloźródłowość” jego artis poeticae:

Określenie to odnosi się do wielowarstwowości wysokiej kultury literackiej poety, który sięgał do uniwersalnych wzorów klasycznych (Owidiusz, Horacy, Jan Kochanowski, Luis Camões, Torquato Tasso, Ewaryst Parny, Franciszek Kniaźnin) i równocześnie szukał prawdy w ludowych

Kaukasus zu den Tscherkessen und Abchasen, nach Kolchis, Georgien, Armenien und in die Krim, Darmstadt 1842-1846).

${ }^{20}$ Giuseppe Gasparo Mezzofanti (1774-1849) był włoskim kardynałem, językoznawcą, profesorem języków semickich (arabskiego, hebrajskiego) w Bolonii, kierownikiem Biblioteki Watykańskiej, przewodniczącym Kongregacji Rozkrzewiania Wiary, wybitnym orientalistą i poliglotą, który władał 38 językami i 50 dialektami. Notabene wzmianka o Mezzofantim świadczy o dobrej orientacji Zabłockiego w europejskich badaniach orientalistycznych.

21 T. Łada-Zabłocki, List do J.I. Kraszewskiego z 8 V 1847, [w:] M. Filina, D. Ossowska, op. cit., s. 249. Zabłocki, pytany przez Kraszewskiego w 1847 r. o kaukaskie „starożytności pogańskie”, odparł: „Chrystianizm a później islamizm wszystko to wytępił”-ibidem, s. 248. Obiecywał jednak Kraszewskiemu zbierać dla niego „numizmata starożytne” (greckie, rzymskie, spartańskie, żydowskie, arabskie, perskie), w jakie obfitowała ta ziemia, a które często służyły do sporządzania amuletów dla miejscowych kobiet. O pracach podjętych przez ziomków na polu literatury, w tym o opisach Kaukazu, donosił też Zabłocki Romualdowi Podbereskiemu. Zob. T. Łada-Zabłocki, List do R. Podbereskiego z 10 VI 1843 roku, [w:] M. Filina, D. Ossowska, op. cit., s. 252-253. Mimo skrajnych warunków i stałego zagrożenia śmiercią polscy zesłańcy prowadzili zatem intensywną eksplorację Kaukazu, jego języków, kultur i przyrody, oraz pilną obserwację bieżących wydarzeń politycznych. Uważali to wręcz za swą patriotyczną powinność: „Pobyt na Kaukazie nie uwalniał nas od obowiązków względem kraju i od pełnienia ich podług zdolności każdego z nas. Niejeden prowadził dziennik lub pisał notatki o prowadzonych tam zaciętych walkach i o ludach, które brały w nich udział" - M. Gralewski, op. cit., s. 14.

Góry, Literatura, Kultura 11, 2018

(C) for this edition by CNS 
opowieściach. Zaś romantyczną afirmację słowa poetyckiego przejmował zarówno od Byrona, Coleridge'a czy Moore'a, jak i od Mickiewicza, Zaleskiego czy Odyńca. Bezpośredni kontakt z kaukaskimi kulturami otwierał mu jeszcze jedno źródło — kulturę Wschodu ${ }^{22}$.

Uważna lektura tekstów pozwala jednak zauważyć, że fascynacja Orientem znacznie wyprzedziła dramatyczne doświadczenia zesłańcze poety w górach Kaukazu oraz jego bezpośredni kontakt z mozaiką kulturową tego egzotycznego dla Europejczyków regionu. Pierwszym źródłem przemyśleń na temat Wschodu była, podobnie jak dla całych generacji poetów dawnych oraz innych polskich romantyków, Biblia.

Wśród utworów Zabłockiego z ,pierwszego okresu” (tj. z lat 1831-1833) natrafimy na wiersz Eden, w którym idealistyczna wizja „krain palmowych” wywiedziona jest z hermeneutyki biblijnej Księgi Rodzaju. Orient jest tu przestrzenią Raju ziemskiego, przechowującą jeszcze jego relikty, a tym samym dającą ukojenie i namiastkę utraconego nieba:

Któż ze śmiertelnych nie słyszał o raju,

$\mathrm{O}$ tej człowieka kolebce pierwotnej?

I któż z Poetów śród nocy samotnej

Nie marzył o tym czarnoksięskim kraju, [...]

Szczęśliwy kraju! cóż się z tobą stało?

Ciebie zniszczyło Boga ramię gniewne;

I tylko w duszy poety zostało,

O tobie jakieś przeczucie niepewne.

I choć zniknąłeś, Edenie szczęśliwy!

Lecz święte miejsce twej niegdyś posady

Jeszcze oszczędził miecz anioła mściwy

Dawnego blasku zostawiając ślady.

Jak pierwsza miłość niewinnego serca,

Jeszcze tam nieba lśnią barwą błękitną,

Jeszcze tam pośród polnego kobierca

Dziewicze róże bez ustanku kwitną.

Jeszcze i teraz wędrowiec daleki

Błądząc w tym kraju, śród północnej ciszy,

W szmerze palm, w szumie starożytnej rzeki,

Odległych wieków jakieś echo słyszy.

Coś tajemnego, coś niepojętego,

Ciśnie mu piersi i na serce pada;

22 D. Ossowska, op. cit. 
I ten uroczy wdzięk wschodu całego,

O jakimś bliskim niebie zapowiada ${ }^{23}$.

Jak zauważyła Janion, „Łada-Zabłocki od początku przejęty był romantyczną ideą wygnania z raju" 24 , która miała w jego przyszłym życiu przełożyć się na dramatyczny i ironiczny wariant osobisty: zsyłkę do krainy, w której miał się niegdyś znajdować ogród Eden, pod berłem carów zamieniony w ziemskie piekło.

Rajsko-arkadyjska wizja cywilizacji azjatyckich sięgała swymi korzeniami czasów najdawniejszych, kiedy to Wschodem (zwłaszcza jego językami) zajmowali się głównie bibliści i teolodzy, a orientalistyka dopiero kiełkowała z biblistyki. To właśnie pierwsi interpretatorzy i komentatorzy Biblii, zgodnie z nielicznymi wskazówkami zachowanymi w Księdze Rodzaju, lokowali ogród Eden $a b$ Oriente $^{25}$. Zresztą nie tylko kultura hebrajska zachowała taką ,„pamięć” Wschodu; podobne asocjacje obecne są w mitologiach różnych ludów: babilońskiej, perskiej, także w greckiej ${ }^{26}$. Tropem doktorów i Ojców Kościoła (św. Izydora z Sewilli, św. Tomasza Akwinaty) podążali (na ogół) pierwsi europejscy orientaliści, podróżnicy i geografowie, przyjmujący istnienie Raju corpolariter i podejmujący próbę ulokowania go na fizycznej mapie Bliskiego Wschodu (np. John Hopkinson w Synopsis paradisi, 1593) ${ }^{27}$ :

23 T. Łada-Zabłocki, Eden, [w:] Poezje Tadeusza Lady-Zabłockiego. Biblijna topika rajska, spleciona z grecką utopią ,wysp szczęśliwych”, pojawia się także w witebskim, adresowanym do „kochanki pierwszych dni”, a pełnym Mickiewiczowskich śladów, miłosnym zaklęciu-przekleństwie Miłość i zemsta poety. Elegia do N... M...r. (Witebsk 1833):,,[...] Gdzie pod przejrzystą gazą nocy wschodniej/ Namiętny słowik wdzięcznej córze wiosny/ Ognistą miłość thumaczy swobodniej/ Tam echa wtórzą jego hymn miłosny/ Tam nie ma ludzi,— tam żywioły sporne/ Jak w dzień stworzenia żyją w wiecznej zgodzie/ To ogród szczęścia, i wiatry wieczorne/ Muzyką pieśni grają w tym ogrodzie. [...] Usłyszysz wtenczas harmoniją świata, Poczujesz matki-ziemi serca bicie; Wszędzie przeniknie twoja myśl skrzydlata. Każdego proszku zbada tajne życie”. T. Łada-Zabłocki, Miłość i zemsta poety. Elegia do N... M...r. [w:] Poezje Tadeusza Łady-Zabłockiego. Poeta kontaminuje tu — zgodnie ze starą tradycją sięgającą jeszcze Ojców Kościoła - wyobrażenie Raju ziemskiego z grecko-rzymskimi przekazami o Wyspach Szczęśliwych. Wschód jawi się jako „ogród szczęścia”, „wyspa szczęśliwa”, pamiętająca jeszcze „dzień stworzenia”: bezpieczna przestrzeń harmonii niezburzonej i niekończącej się wiosny, gdzie „żywioły sporne” żyją „w wiecznej zgodzie”. Romantyczna świadomość utraty Raju, empirycznej nieosiągalności utopii, wyraża się jednak w odebraniu tej przestrzeni realności ontologicznej; nie daje się już ona zlokalizować geograficznie, wysnuta jedynie z wyobraźni „w młodości zaranku", możliwa jest do odtworzenia wyłącznie dzięki miłości.

${ }^{24}$ M. Janion, Tadeusz Łada-Zabłocki, [w:] Obraz literatury polskiej. Literatura krajowa w okresie romantyzmu 1831-1863, t. 3, red. S. Żółkiewski et al., Warszawa 1992, s. 352.

25 Zob. J. Delumeau, Historia Raju. Ogród rozkoszy, przeł. E. Bąkowska, Warszawa 1996, s. $5-25,146-159$.

${ }^{26} \mathrm{Na}$ przykład w micie o wyprawie argonautów po złote runo, w którym Kaukaz jest krainą obfitości, dostatku, „mlekiem i miodem płynącą”.

27 Zob. J. Delumeau, op. cit., s. 134-135. Św. Tomasz z Akwinu stawiał na okolice równika (linia ekwinokcjalna) ze względu na łagodność klimatu, inni — na Indie i Cejlon, po epoce odkryć geograficznych zaś pojawiała się „hipoteza amerykańska”, wskazująca na Nowy Świat (np. Brazylię). John Milton lokował „Raj utracony” w Asyrii. Dominowała jednak lokacja blisko- lub środko-

Góry, Literatura, Kultura 11, 2018

(C) for this edition by CNS 
W wieku XVI i XVII ukształtowały się w zasadzie trzy konkurencyjne lokalizacje, którymi obdzielili się najwybitniejsi komentatorzy Genesis: Armenia, Mezopotamia i Ziemia Święta. Wszyscy oni prawie jednogłośnie utrzymywali, że wyrażenie a principio w Wulgacie należałoby zamienić na ab Oriente, a zatem zamiast plantaverat autem Deus paradisum voluptatis a principio (Rdz 2,8$)$, byłoby: plantaverat Deus hortum ab Oriente. Takie zresztą znaczenie nadawała tym słowom między innymi Septuaginta i ojcowie greccy. Grzegorz z Nyssy poprzez tę geografię tłumaczył zwracanie się podczas modłów ku wschodowi: „Modląc się zwracamy się ku wschodowi, bo na wschodzie była nasza pierwsza ojczyzna, raj, z którego wyszliśmy"28.

Wielu autorów wskazywało na całą strefę ciągnącą się od stóp Kaukazu do Zatoki Perskiej (a nawet Arabii Szczęśliwej), tj. na Persję, Armenię, Kolchidę, Arabię (Syrię-Palestynę) i Mezopotamię, jako prawdopodobną praojczyznę potomków Adama ${ }^{29}$. Biskup Agostino Steuco (Steuchus Eugubinus) w swoim słynnym dziele o Starym Testamencie (Veteris testamenti ad Hebraicam veritatem recognitio, Lyon 1531) zwrócił nawet uwagę na istotny fakt „geojęzykowy” - mianowicie staroirańską etymologię greckiego słowa paradeisos (łac. paradi$s u s)^{30}$. Ta „rajska geografia”, raz mniej, raz bardziej naukowa w swych dociekaniach i spekulacjach, zwłaszcza zaś hipoteza armeńska i mezopotamska, czyniły góry Kaukaz przestrzenią transgresji szczególnego rodzaju: progiem Azji, bramą Orientu i zarazem wrotami utraconego ziemskiego Raju.

Oczywiście wskazane rajskie reminiscencje wschodnie nie wyczerpują zasobu orientaliów w poezji Zabłockiego. Już w latach trzydziestych czytał on poezje Hafeza w przekładzie swojego przyjaciela jeszcze z czasów studiów w Moskwie (a zarazem przyjaciela Adama Mickiewicza) - filomaty Jana Wiernikowskiego. Nawiązujący stylistycznie do Pieśni filaretów biesiadny wiersz Do przyjaciót. Pieśń przy winie został nawet opatrzony mottem z gazelu szirazkiego mistrza:

Nie ma na świecie choć by’ś zbiegł cały, I choć by'ś szperał w potoku wieków,

Nie ma na bóle, serca upały

Dzielniejszych nad wino leków ${ }^{31}$.

Z kolei podejmującą romantyczny topos „rodzinnej rzeki” elegię Do Dźwiny poprzedza cytat zaczerpnięty $\mathrm{z}$ arabskiego manuskryptu, rozpowszechniony w Europie dzięki Byronowi, który sparafrazował go w swej powieści poetyckiej

wowschodnia. Pierwszymi Bibliami zaopatrzonymi w mapy lokujące Eden (zwykle na wschód od Babilonu) były Biblie luterańskie i kalwińskie.

28 J. Delumeau, op. cit., s. 150.

29 Zob. ibidem, s. 151.

30 Zob. ibidem, s. 157.

31 T. Łada-Zabłocki, Poezje, s. 42. 
Narzeczona z $\operatorname{Abydos}^{32}$ (po nim sięgali po ten passus liczni naśladowcy, przyczyniając się do wielkiej kariery tego urywku w literaturze angielskiej ${ }^{33}$ ):

I came to the place of my birth and cried: „the friends of my youth! where are they?" and an echo answered: ,where are they?" Arabic MS

Reminiscencja wschodnia/muzułmańska pojawia się też w nostalgicznym miłosnym nokturnie Zabłockiego Duma nocna:

O czemuż nie mogę zdruzgotać okucia

Co rozdzielają mię z kochanką;

I w pełnem wezbraniu świętego uczucia

Do stop twych upaść, o niebianko! [...]

Ach był by’m szczęśliwy, aniele mój stróżu, By'ś błysnął wtenczas memu oku,

Gdy'm stał tak niepewny na życia rozdrożu, W szesnastym życia mego roku.

$[\ldots]$.

Ach wtenczas młodości manowiec bezdrożny Mnie oświeciła by'ś z wysoka;

32 Zob. G.G. Byron, The Bride of Abydos. P. XVII, [w:] idem, The Complete Works of Lord Byron, Paris 1841, s. 222, https://books.google.pl/books?id=qqtKAQAAMAAJ\&pg=PA222\&lpg=PA222\&dq=I+came+to + the + place + of + my + birth + and + cried: $+\%$ E $2 \% 80 \% 9$ Ethe + friends + of + my + youth ++ where + are + they? $\% 22+$ and + an + echo + answered: $+\%$ E2\% $\% 0 \% 9$ Ewhere + are + they $\&$ source $=$ bl\&ots $=-$ MOW8KX3ZZV\&sig=xO1VP-AGOOkJ67tfa7IBOm-9GBo\&hl=pl\&sa=X\&ved=0ahUKEwixs jfn-nPAhXEhywKHTUKAqIQ6AEIMjAE\#v=onepage $\& q=I \% 20$ came $\% 20$ to $\% 20$ the $\% 20$ place $\% 20$ of $\% 20$ my $\% 20$ birth $\% 20$ and $\% 20$ cried $\% 3 \mathrm{~A} \% 20 \%$ E2\%80\%9Ethe $\% 20$ friends $\% 20$ of $\% 20$ my $\% 20$ youth! $\% 20$ where $\% 20$ are $\% 20$ they $\% 3 \mathrm{~F} \% 22 \% 20$ and $\% 20$ an $\% 20$ echo $\% 20$ answered $\% 3 \mathrm{~A} \% 20 \% \mathrm{E} 2 \% 80 \% 9 \mathrm{E}-$ where\%20are\%20they\%3F\&f=false (dostęp: 27.03.2017).

${ }^{33}$ Zob. m.in. „The World of Fashion”, London 1 January 1841, https://books.google.pl/book$\mathrm{s}$ ? id=189eAAAAcAAJ\&pg=PA11\&lpg=PA11\&dq=I+came+to+the+place +of + my + birth + and + crie$\mathrm{d}:+\% \mathrm{E} 2 \% 80 \% 9 \mathrm{Ethe}+$ friends + of + my + youth! + where + are + they $\% 22+$ and + an + echo + answere$\mathrm{d}:+\% \mathrm{E} 2 \% 80 \% 9$ Ewhere+are + they? \& source $=$ bl\&ots $=\mathrm{c} 8 \mathrm{ZqyaD} 0 \mathrm{GZ} \&$ sig $=18$ wnkRpiK $5 \mathrm{dI} 8$ no9OKooB8jiDWc\&hl=pl\&sa=X\&ved=0ahUKEwixs_jfn-nPAhXEhywKHTUKAqIQ6AEIJjAB\#v=onepage\&q\&f=false (dostęp: 27.03.2017); C.G. Godwin, The Voice of the Wilderness, [w:] eadem, Lyrics of the East, „Blackwood's Edinburgh Magazine” 32, 1832, cz. II, s. 681, https://books.google. $\mathrm{pl} /$ books? $\mathrm{id}=$ wPDQAAAAMAAJ\&pg $=$ PA681\&lpg=PA681\&dq $=\mathrm{I}+$ came + to + the + place + of + my +birth + and + cried: $+\% \mathrm{E} 2 \% 80 \% 9 \mathrm{Ethe}+$ friends + of + my + youth!+where + are + they? $\% 22+$ and + an + echo + ans wered:+\%E2\% $80 \% 9$ Ewhere+are+they? \&source=bl\&ots=BdThI3ZMKU\&sig=y97BJHL3vy-mkzOqm6peAQFV-DQ\&hl=pl\&sa=X\&ved=0ahUKEwixs jfn-nPAhXEhywKHTUKAqIQ6AEILjAD\#v=onepage\&q\&f=false (dostęp: 27.03.2017)

Góry, Literatura, Kultura 11, 2018

(C) for this edition by CNS 
I ja by’m cię uczcił jak pielgrzym pobożny

Grób Mekkańskiego czci proroka.

(Duma nocna, Witebsk 1835) ${ }^{34}$

W tym pełnym wschodniej czołobitności wyznaniu, w którym miłosne oddanie zyskuje siłę religijnej niemal czci, mowa jest o drugim po Mekce celu pielgrzymek pobożnych muzułmanów: grobie Proroka Mahometa w meczecie Al-Masdżid an-Nabawi w Medynie ${ }^{35}$. W innym wierszu, złożonym w hołdzie witebskiej piekarce dzielącej się bez rozgłosu chlebem z ubogimi, poeta przyrównał adresatkę do anioła sprawującego opiekę nad matką protoplasty Arabów (Ismaela) - niewolnicą Agar ${ }^{36}$.

Wśród poezji „drugiego okresu” (witebskiego, przedzesłańczego) zwraca uwagę tekst opublikowany w „Rubonie” w roku 1847, w tomie 7, pod tytułem Do N... P... T...eff. Wyjeżdżającej w podróż do Krymu (Prużki 1834) ${ }^{37}$. Planowany wyjazd bliskiej sercu poety adresatki (i to kilku wierszy Zabłockiego - nieznanej niestety z nazwiska) stał się pretekstem do odbycia i przez niego, choć już wyłącznie imaginacyjnej, podróży na Krym — podróży, której poszczególne „stacje” zostały określone przez obrazy zapamiętane z Mickiewiczowskich Sonetów krymskich (Salgir, Czatyrdah, mogiła Potockiej w haremie itd.). Bez wątpienia wiersz ten był poetyckim hołdem złożonym wieszczowi, a także śmiałą próbą zmierzenia się z nim na piękno opisów i bogactwo poetyckiej wyobraźni, zamkniętej w miniaturze podróżniczej. Utwór pozostaje również ważnym świadectwem twórczej recepcji orientalnego arcydzieła Mickiewicza oraz roli tego ostatniego w rozbudzaniu fascynacji innych polskich romantyków krajami Wschodu $^{38}$. Kulminacyjne wersy zdradzają marzenie Zabłockiego (niepewnego wówczas swych dalszych losów, bo przecież oczekującego z niepokojem na koniec procesu i wyrok) o wyprawie na Krym, a nawet o związaniu się na stałe z tą oswojoną dzięki Mickiewiczowi krainą:

Oby’m mógł, jeśli niebo dla mnie się przechmurzy,

Polecieć w ślad za tobą, bez trwogi i strachu,

I łódkę życia mego, skołataną w burzy,

Przywiązać do Czatyrdahu ${ }^{39}$.

34 T. Łada-Zabłocki, Duma nocna, [w:] idem, Poezje, s. 95-96.

35 Pierwszy meczet w tym miejscu został zbudowany przez samego Proroka i przylegał do jego domu. Tym, który „odwiedzał Proroka grobowce”, był w świadomości polskich romantyków przede wszystkim Wacław Rzewuski - Duma o Wacławie Rzewuskim ukazała się w 1833 r. w trzecim paryskim tomie Poezji Słowackiego, być może wiersz Zabłockiego jest jakimś „,przebłyskiem” jej strof.

36 Zob. T. Łada-Zabłocki, Luizie Wrehe, piekarce witebskiej, [w:] idem, Poezje, s. 102.

37 Zob. Z poezji nie ogłoszonych nigdzie Tadeusza Łady-Zabłockiego, „Rubon” 7, 1846, s. $152-156$.

${ }^{38}$ Zob. T. Łada-Zabłocki, Do N... P... T...eff. Wyjeżdżajacej w podróż do Krymu, Prużki 1834, „Rubon” 7, 1846, s. 153-156. Przemierzając później krainy Orientu, Zabłocki sam często wchodził w rolę Mickiewiczowskiego pielgrzyma.

39 Ibidem, s. 156.

Góry, Literatura, Kultura 11, 2018

(C) for this edition by CNS 
Spodziewając się kary wygnania i żegnając się z bliskimi, miał jednak Zabłocki nadzieję powrócić i przywieźć do kraju wieść o tamtych odległych stronach i ich mieszkańcach:
Żegnam cię, Jozafacie! choć za świata kraniec
Zdradziecki bałwan łódź moję wyrzuci;
Zawsze stron lepszych wygnaniec,
Myślą do progów rodzinnych powróci,
$[\ldots]$
I opiszę ci wzajem cudowne przygody,
Com spotkał w swej pielgrzymce po zaświatnej fali!
Jakie tam żyją narody.

I jakim blaskiem gwiazda ducha w nich się pali!... [...]

(Do J. J., Witebsk 1855) $)^{40}$

Przykłady te pokazują dobitnie, że Wschód, jego kultura i literatura, stanowiły od samego początku wyposażenie bogatej, erudycyjnej wyobraźni poetyckiej Zabłockiego (oraz przedmiot jego marzeń), niemal na równych prawach z tekstami literatury starożytnej (Horacy, Wergiliusz, Owidiusz), angielskiej (Milton, Szekspir, Felicia Hemans, Robert Southey, Francis Thompson, Coleridge, Byron, Thomas Moore, Georg Chapman), francuskiej (d'Alembert, Rousseau, Lamartine, Chateaubriand, Hugo), niemieckiej (Schiller), hiszpańskiej (Esteban Manuel de Villegas), włoskiej (Dante), portugalskiej (Camões) i oczywiście polskiej (Mickiewicz, Słowacki, Stefan Witwicki, Tomasz August Olizarowski). $\mathrm{W}$ tematykę wschodnią wprowadzały poetę nie tylko filomackie tłumaczenia poezji Orientu pióra Jana Wiernikowskiego i Aleksandra Chodźki ${ }^{41}$ czy dzieła Mickiewicza (przede wszystkim Sonety krymskie i odeskie), lecz także poezja Byrona, Thomasa Moore'a (autora poematów o tematyce orientalnej Lalla Rokh, The Veiled Prophet of Khorassan) i uważanych dziś za pomniejszych (a w XIX w. bardzo cenionych) twórców angielskich, jak Felicja Hemans, której wiersz Palma poddał nawet swobodnej przeróbce ${ }^{42}$.

Zsyłka na Kaukaz brutalnie zderzyła młodego poetę z nagą rzeczywistością Orientu targanego rosyjską agresją — rzeczywistością niebotycznie odległą od literackich obrazów Wschodu-Raju czerpanych z młodzieńczych lektur. Bramy dawnego Raju stały się wrotami udręki, granicą oddzielającą boleśnie i nieodwołalnie od „przeszłego szczęścia” i „znikłej rozkoszy”, od utraconych bliskich i dalekiej ojczyzny:

40 T. Łada-Zabłocki, Do J. J., „Atheneum” 3, 1844, s. 163-165.

41 O zażyłości Zabłockiego z poezją Aleksandra Chodźki świadczy zaczerpnięte z niej motto figurujące przed lirykiem Do Zary, pisanym w Carskich Kołodcach 10 lipca 1838 r.

42 T. Łada-Zabłocki, Palma. Elegia, [w:] idem, Poezje. 
Spod wieńca różnofarbnych chmur

Posępnie sterczą szczyty gór

Jak fale zamrożone morza;

Za nimi pełen życia świat,

Za nimi pamięć błogich lat,

Za niemi szczęścia mego zorza.

(Do mojej matki) ${ }^{43}$

Obraz usychającej brzozy, której nasiona nieopatrznie przyniósł na Wschód północny wiatr, tworzy sugestywną wizję losu zabłąkanego w obce strony zesłańca:

Lecz cóż się stało, że z taką chwałą,

Zacząwszy życie pod niebem Wschodu,

$Z$ wolna więdniejesz, i już nie siejesz

Dobroczynnego wokoło chłodu? [...]

Zakwitniej pośród Kaukazkich lasów.

Dziewica piękna jak kwiatek sadu,

Nieraz cię rączką obwinie,

I pełzający liść winogradu

Gęstym cię płaszczem ochynie.

I ja znużony, często w te strony

Przyjdę sam jeden z bliskiego szańca,

I zabrzmię tobie w czarnej żałobie

Dziką, posępną piosnkę wygnańca.

(Do brzozy w górach kaukaskich)

Kaukaski Orient stał się w pierwszej chwili krainą wygnania — obcą, złowrogą i przerażającą. W górach czaiła się śmierć, której przeczucie nie opuszczało poety-żołnierza niemal nigdy. Jednak uwięziony „pod niebem Wschodu” dostrzegł w końcu jego czarującą, egzotyczną odmienność, którą starał się oddać za pomocą środków typowych dla poezji orientalnej: hiperbol, metafor, zmysłowych, rozbudowanych opisów:

Jak ciepłe słońce! jak niebo przejrzyste!

To niebo Wschodu, - to Azyi słońce

Ciska wokoło promienie ogniste

$\mathrm{Na}$ fale płynnem srebrem gorejące,

Co utrudzone po nocnym obiegu

Drzemią spokojnie na piaszczystym brzegu.

43 T. Łada-Zabłocki, Do mojej matki, [w:] idem, Poezje. O ile nie zostanie to zaznaczone inaczej, wszystkie cytaty z dzieł poetyckich Zabłockiego będą w dalszej części opracowania przytaczane za tym wydaniem. 
Czasem się ockną szmaragdowe tonie,

I całe morze, jak go zajrzysz okiem,

Błyśnie gwiazdami, pożarem zapłonie,

I zamigoce błyskawic potokiem.

To coś tęsknego do serca zagwarzy,

To znów zasypia i o niebie marzy.

(Duma. Nad brzegiem Morza Kaspijskiego)

Szczególnie malarski jest obraz gwałtownej burzy z piorunami, odbijającej się krwawym światłem w lustrze wypełniającego puchar wina, z wiersza Toast w czasie burzy (1838):

Burza! - Na nocy zasępionej szacie

Gdzieniegdzie jasny piorun się zapala;

Cicho i pusto w samotnej komnacie!...,

Ciemnoczerwona Kachetii fala

Szumiąc w pucharze posępnie przełyska,

Gdy na nią potop błyskawicy spadnie,

Lub z tlejącego w kominku ogniska

Umierający promień się wykradnie.

(Toast w czasie burzy)

Jeszcze większa sugestywność cechuje obraz wschodniego nocnego nieba w jednej z opublikowanych w „Rubonie” (w roku 1847) hymnicznych Pieśni świętych, spisanych u podnóża świętej góry Ararat:

Zdumiewającej budowy świata

Ty jesteś, Boże, światłem i życiem,

Blask dnia i nocy godowa szata

Są tylko słabym Ciebie odbiciem. [...]

Po niebie, ziemi, gdy noc ponura

Skrzydła z gwiaździstej ciemni roztoczy,

Niby ptak czarny, którego pióra

Zdobią tysiączne błyszczące oczy:

Ta święta ciemność, te ogniów roje

Tak wielkie, liczne, Panie! są Twoje!

(Dwie pieśni święte (pogrobowe), Kulpy u podnóża Araratu 1847) ${ }^{44}$

Z czasem „geopoetyka” wierszy pisanych „za Kaukazem” przez „z Północy błędnego wygnańca" zyskiwała coraz bardziej wyraziste znamię wschodnie. Środki tej orientalizacji były różnorodne i obfite: od kaukaskich realiów krajobrazowo-kulturowych po językowe zapożyczenia i wschodnie formowanie struktury poetyckiej wyobraźni.

44 T. Łada-Zabłocki, Dwie pieśni święte (pogrobowe), Kulpy u podnóża Araratu 1847, „Rubon" 10,1847 , s. $175-176$. 
Do strof Zabłockiego zaczęła przede wszystkim coraz śmielej wkraczać orientalna przyroda, np. nieznane w Polsce i na Litwie drzewa migdałowe:

Władysławie, lubię twoje pieśni,

Czy gdy-ć w świętych chwilach zamyślenia

Płyną z serca bolejącej cieśni

Niby potok spod migdałów cienia.

(Do Władysława Strzelnickiego)

Albo figowe:

Zwierciadło niebios! o jakże wspaniale,

Twoje się łono niespokojne wzdyma!

Szumij, — przetaczaj pieniące się fale

Przed okiem — krajów odległych pielgrzyma.

Zagraj mu, zagraj, hymn potęgi dziki

W którym usłyszeć można po kolei

Jęki rozpaczy, radości okrzyki,

I przytłumione westchnienie nadziei.

Lubię gdy twoja otchłań się rozjaśni,

Gdy ty się w niebios obliczu weselisz.

[...]

Gdy pod namiotem figowego listka

Przy cichym szmerze fali wietrzyk zaśnie,

I gdy w milczeniu patrzy ziemia wszystka

Jak słońce w twoich złotych nurtach gaśnie.

(Nad Morzem Azowskim, Taganrog 1837)

Pojawiły się też w tych zakaukaskich strofach inne okazy wschodniej flory: banany, brzoskwinie, platany (zwane z turecka czynnarami), kokosy, morwy, drzewa oliwne, palmy, pomarańcze i mirty, a nawet nazwy lokalnych kaukaskich win (kachetia $)^{45}$. W liście do Kraszewskiego z 15 lutego 1843 r. pisał Zabłocki o wiosennym przebudzeniu przyrody w Tyflisie: ,migdały kwitną i winogrona się rozwijają"46. Zauważalne stało się również stopniowe wysycanie języka poezji zapożyczeniami z tureckiego, tworzącymi „wyraźny krąg słowny”, służący nazywaniu orientalnych realiów (np. air, aut, namaz, odaliska, czynnar, szater itd.) ${ }^{47}$. Szeroki wachlarz nazw miejscowych (miast i wiosek, mieszkańców, plemion, rzek, mórz, gór, szczytów, wodospadów itp.) wprowadzał konkrety geograficzne Gruzji, Armenii, Azerbejdżanu i łańcucha Kaukazu ${ }^{48}$.

45 Zob. J. Brzeziński, Ojęzyku poezji Tadeusza Łady-Zabłockiego, Zielona Góra 2001, s. 50-51.

46 T. Łada-Zabłocki, List do J. I. Kraszewskiego z 15 II 1843 roku, s. 244.

47 Zob. J. Brzeziński, op. cit., s. 63-64.

48 Zob. też R. Gadamska-Serafin, Góry Kaukaz w poezji zesłańczej Tadeusza Łady-Zabłockiego, „Góry - Literatura - Kultura” 9, 2015, s. 155-190, http://glk.sjol.eu/category/9-2015-452 (dostęp: 27.03.2017). 
Liczna jest grupa liryków ukazujących życie kaukaskich górali i piękno otaczającej ich przyrody. Na uwagę zasługuje zwłaszcza elegia Alazańska Dolina $\mathrm{z}$ roku 1838 :

Oblask wieczoru spłynął szkarłatnym potokiem

Na piękne Gruzji wzgórza;

Alazańska dolina przysłoniona mrokiem

We mgle się srebrnej zanurza.

$[\ldots]$

Dalej czerni się puszcza, jak cień śpiącej chmury,

A za nią na kształt olbrzymów,

Lodowate Kaukazu podnoszą się góry,

Obwiane całunem dymów.

Gdzieś tam wszczęła się burza. - i kłęby mgły szarej

Zerwane z gór niedostępnych

Przepływają dolinę, - i zamku Tamary ${ }^{49}$

Czepią się szczytów posępnych.

I wszystko pociemniało, - i wszystko zacichło,

Tylko pode mgłą wilgotną,

Potok, - niby z marzenia obudzony rychło,

Głośniej brzmi skargę samotną.

Tylko kiedy niekiedy jakiś ptak zagrucha

Skryty w szerokich fig chłodzie;

Lecz, ot! stoczył się księżyc ze skały, — i słucha

Życia w uśpionej przyrodzie.

49 Mowa o królowej Tamarze, władającej Gruzją w XII w. Zabłocki dołączył do elegii obszerne objaśnienie na temat tej władczyni, interesowali go bowiem nie tylko współcześni, lecz także historyczni mieszkańcy Kaukazu: „Królowa Tamara, córka Jerzego III panowała od 1171 do 1191. Ten przeciąg czasu był najświetniejszym okresem dziejów i piśmiennictwa Gruzji. Czarujący jest obraz jej panowania skreślony w Sakartwelo. Zawojowanie Aderbedżanu, Trapezontu i Gandży, przyprowadzenia do posłuszeństwa Armenii, kilkakrotne rozbicie Sułtana Nukardine i Szacha Ata-bega, słowem: uśmierzenie wszystkich zewnętrznych nieprzyjaciół, pokój wewnętrzny, postęp sztuk i nauk, których wiecznym pomnikiem pozostanie bohaterski poemat Rustawel'a pt. Skóra Lamparta , oto są zasługi Tamary, która lubiła nazywać siebie Królową-Królem. Krótki lecz świetny był ten okres. Pod jej następcą Jerzym IV Laszą,- Czyngis-Chan podbiwszy Persją, obrócił swój oręż na Gruzją, zniszczył ją ogniem i mieczem i zagasił jutrznię cywilizacji i dobrego bytu narodu. Panowanie córki Tamary Rusudany, sławnej w dziejach Wschodu swoją pięknością, którą w małoletności Dawida, syna Jerzego IX Laszy, objęła ster rządu, wcale nie przyczyniło się do naprawienia skołatanego państwa, co prowadząc ciągłe wojny z sąsiadami, lub ulegając naprzemian dumnym wojownikom Wschodu, nigdy już nie mogło powrócić do pierwszej świetności. I dla tego sława Tamary przesila wieki i przechowała się w sercach odległych potomków, którzy jej przypisują wszystkie pomniki starożytnej Gruzji” - T. Łada-Zabłocki, Alazańska dolina, [w:] idem, Poezje.

Góry, Literatura, Kultura 11, 2018

(C) for this edition by CNS 
I wszystko się pod jego rozświetliło blaskiem,

I tuman pierzchać zaczyna;

Nad brzegiem Alazani, — pod samotnym laskiem

Pełga ognisko Lezgina. [...]

(Alazańska dolina)

Z kolei ze szczytu „Szemachyńskiej góry” spoglądał poeta na „nędzne Tatarów chałupy, / Ocienione gajami morw, fig i migdałów" 50 .

Wizerunek rdzennych mieszkańców gór Kaukazu jest w poezji Zabłockiego ambiwalentny — raz zyskują oni jakże typowe dla romantycznego portretu górali cechy jednostek szlachetnych, wolnych, bitnych i nieujarzmionych, innym razem epitet „Wschodu syn” staje się synonimem azjatyckiego barbarzyństwa, zwłaszcza w kolejnych nekrologach, spisywanych poległym towarzyszom broni: Adamowi „M-skiemu” i Feliksowi Ordyńskiemu:

A serce w którem brzmiąca fala,

I niebios blask, i kwiatów woń,

Znalazły oddźwięk, — już górala

Pastwiąca się wydarła dłoń.

Zaginie pamięć o nim wszędzie,

Jak światu niewiadomy czyn,

Kościami jego igrać będzie

$\mathrm{Z}$ urągowiskiem Wschodu syn.

(Pamięci Zenona M...skiego);

Łzy gorzkie com na twej mogile rozsypał

Pod wieczór wiatr stepów wypije;

A kurhan grobowy com tobie usypał,

Pojutrze Czeczeniec rozryje!

(Na śmierć Feliksa Ordyńskiego poległego w bitwie z góralami)

Realizm, a nawet zacięcie etnograficzne, uwidaczniają się w pisanej w $1839 \mathrm{r}$. w Achtach w Lezgii „na nutę tańcu Lezgińskiego” Lezgince. Wschodnia stylizacja jest w tym utworze posunięta najdalej, sięga bowiem w głąb tkanki wiersza i dotyczy całego przedstawionego w nim świata. Tekst był prawdopodobnie inspirowany jakąś oryginalną pieśnią ludową, być może wchłonął nawet jej fragmenty, a jego tytuł odnosi się do tradycyjnego, bardzo dynamicznego (metrum 6/8) i skocznego tańca ludowego (zwanego też islamey bądź czeczenka), stworzonego przez „nieujarzmionych” kaukaskich Lezginów ${ }^{51}$.

Taniec ten, do dziś popularny w Gruzji, Czeczenii i Dagestanie, charakteryzuje się drobnymi, szybkimi krokami oraz gwałtownymi ruchami ramion i ciała.

50 T. Łada-Zabłocki, Widok Szyrwanu ze szczytu Szemachyńskiej Góry, [w:] idem, Poezje.

51 Lezgini zamieszkiwali południowo-wschodni Dagestan i północny Azerbejdżan, jednak w XIX w. często określano tym mianem wszystkich mieszkańców Dagestanu. 
Tancerze często upadają na kolana, by zaraz szybko z nich powstać. Znamienne jest także przyjmowanie „pozy orła” — ptaka gór: z lekko wzniesionymi do góry, rozpiętymi ramionami. Lezginka - choć tańczą ją również kobiety — sprawia wrażenie tańca męskiego, mającego na celu głównie demonstrację zręczności, odwagi i fizycznej siły. Nie bez powodu kaukascy górale wykonywali ją przed bitwą, połyskując przypiętymi do ubrań krótkimi mieczami.

Dominujące w wierszu Zabłockiego rymy męskie akcentują mocny rytm linii melodycznej lezginki, odbijający ognisty temperament mieszkańców Kaukazu. Wschodnia metaforyka miłosna („,różo wschodnich róż”, „wdzięczna róża Dagestanu"), realia geograficzne (Dagestan, twierdze Nucha i Zakatały, rzeki Samur, Kasp i Alazań), onomastyczne (imię żeńskie: Hajar, męskie: Ali), obyczajowe (lezginka, handżar ${ }^{52}$, złoto, jedwabie), przyrodnicze (czynar — platan), religijno-mitologiczne (Monker) i językowe (giaur) tworzą spójny, bogaty obraz muzułmańskiego Kaukazu:

Hadżar! różo wschodnich róż!

Prędzej mię uściskiem darz;

Bo jak Monker, grobów stróż,

Idę Giaurom zajrzeć w twarz,

Za Kaukazu śnieżne wały

Poza Nuchę, Zakatały.

Przy mnie trafna moja broń,

Przy mnie chandżar pocisk chmur,

I towarzysz bitew - kon,

Co to nieraz z wierzchu gór,

Na przelękłe ich kolumny

Spadał niby Samur szumny.

Nie wiesz jak to słodko w cwał

Lecieć wpośród rannej mgły,

Jak burzliwy Kaspu wał;

Jakie mary, jakie sny

Plączą sie podówczas w głowie,

Żaden ć' język nie wypowie.

Póki w sercu kipi krew

Muszę toczyć z wrogiem bój,

Nie płacz, proszę, dziewo dziew!

Jeszcze wróci Ali twój

I przywiezie jak w korabiu

Złota, srebra i jedwabiu.

52 Wschodni sztylet o charakterystycznym, zakrzywionym kształcie; puginał, kindżał. 
Co dostarczyć może Wschód,

Wszystko z rąk odbierzesz mych,

Dary ziemi, dary wód;

Wtenczas w gronie drużek swych

Zajaśniejesz jak śród łanu

Wdzięczna roża Dagestanu.

Piękna Hadżar patrzy nań’, I łzy gorą w oczach jej:

$\mathrm{Na}$ co mi bogata dań.

Dosyć dla mnie duszy twej, Jedź więc i za dary nowe

Wywieź z boju własną głowę.

Zniknął Ali w kłębach mgły,

Zacichł tentent końskich nóg,

Długo, ach! Hadżary łzy

Pył zruszały krętych dróg,

Próżne żale i modlitwy

Już nie wróci Ali z bitwy.

Tam gdzie Alazani zdrój

Czerpa fale z piersi chmur,

Długo kipiał krwawy bój

I ty'ś poległ, synu gór!

Pod czynarem, na kurhanie

Wieczne'ć dano pomieszkanie.

(Lezginka)

Autor dołączył do wiersza takie oto kulturowe objaśnienie, wywiedzione $\mathrm{z}$ arabskiej mitologii i Koranu (odsyłacz wskazuje, że Zabłocki korzystał z jego francuskiego przekładu):

Kiedy człowiek umiera, dwaj straszni Aniołowie Monker i Nakir przychodzą zdjąć ze ń’ rachunek życia. Każą mu podnieść się na nogi i zadają mu pytania o jedności Boga i posłannictwie proroka. Jaki jest twój Bóg, twój prorok, twoja wiara — zapytują go? i jeżeli postrzegą że on jest niewierny, uderzają go strasznym sposobem. Elgazel. Talmudziści utrzymują podobnąż prawie wiarę. Jeżeli człowiek umiera, powiadają, anioł śmierci usiada na jego grobowcu. Natychmiast dusza łączy się z ciałem. Obżałowany powstaje na nogi, a anioł zaczyna go badać, i jeżeli pozna, że jest winowajcą, uderza go łańcuchem, którego jedna połowa zrobioną 
jest z żelaza, a druga z ognia. Patrz: Le Coran, traduit de l'Arabe par Savary. Cap. VIII Note ${ }^{53}$.

Orient najsilniej przemawia jednak w erotykach Zabłockiego. Ich odurzająca, gęsta zmysłowość zdaje się najmocniej przylegać do wyobrażeń Wschodu jako krainy ekstatycznej miłości i namiętnych, czarnookich piękności. Scena podglądania z ukrycia nagiej, kąpiącej się „afrodyty” kaukaskiej przywodzi wręcz na myśl najśmielsze pomysły Stanisława Trembeckiego (por. wiersz Wanna):

Pod cieniem winogradów, brzoskwiń i czynnarów

Widziałem zaczajony afrodytę drugą:

Płynęła okolona jasnym wieńcem czarów,

Rozpuściwszy na falę wstęgę ciemną, długą,

Lśniącego się warkoczu; - a Terek zbudzony

Rannym oddechem stepów, — nad jej ciałem śnieżnem

Snuł z rubinów i pereł przejrzyste zasłony,

I nęcił do rozkoszy szemraniem lubieżnem.

Piękna Rusałko! władzą wszechwładną zaklęcia

Zmień mię w falę błękitną, - a pełen radości,

Całując, pieszcząc, łechcąc i tuląc w objęcia

Uniosę cię na wyspę szczęścia i miłości.

(Rusałka Tereku Kalinów, 5 czerwca 1842)

Ten śmiały erotyzm miał jednak i bolesne oblicze; zesłanie uderzało nie tylko w wolność skazańców, ale całkowicie rujnowało ich życie prywatne, osobiste. Najokrutniejszy aspekt wieloletniej służby wojskowej krył się w pozbawieniu więźnia szans na realizację elementarnych ludzkich pragnień, wyrastających z potrzeby kochania. Tęsknota za miłością znajduje w tej poezji jakąś namiastkę spełnienia w przelotnym, gorącym romansie pośród bujnej wschodniej przyrody — romansie prawdziwym lub tylko wyimaginowanym:

Chwila dumań. - Już pomroka

Osłoniła senny gaj.

Przyjdź dziewico czarnooka

Przyjdź i przynieś z sobą raj!

Raj objęć twych

I niebo oczu;

Dzień spojrzeń ich

I noc warkoczu;

Ja do serca cię przytulę

I wypiję słodycz z ust;

${ }^{53}$ Poezje Tadeusza Lady-Zabłockiego. 
Gwiazdy - siostry spojrzą czule

Cicho zadrży świadek — chrust.

(Romans)

„Córa wschodniej krainy”, obdarzana orientalnymi imionami: Zara ${ }^{54}$ (o etymologii arabskiej) lub Nizza, często jest tylko ulotną „,wypieszczoną marą”, wywiedzioną z wyobraźni lub pamięci:

I Zara, córa powietrza i słońca,

Miła - jak pamięć uroków,

Piękna jak palma w pustyni kwitnąca,

Przybędzie z jasnych obłoków.

(Wiersz pisany dwudziestego listopada Carskie Kołodce 1838)

54 Niewykluczone, że imię Zara (czasem w wersji „Zahra” lub „Zahara”, od arabskiego jo zahra 'jasna, lśniąca, promienna' bądź jo zahrah 'kwiat, kwiatuszek' — łączone z biblijnym „Sarah”) nosiły różne muzułmańskie piękności, które Zabłocki spotykał w kaukaskich aułach i miasteczkach. Ma ono wprawdzie etymologię arabską, ale ponieważ tak nazywała się jedna z córek Mahometa (Fatimah Zahra), rozpowszechniło się ono wraz z islamem w różnych krajach Bliskiego Wschodu (prócz Arabii zwłaszcza w Persji).

Wiedza o szerokiej erudycji Zabłockiego skłania jednak do poszukiwania literackiej genealogii tego imienia. Autor mógł je zaczerpnąć ze „wschodniej” powieści poetyckiej Słowackiego zatytułowanej Mnich (twórczość Słowackiego stanowiła dlań ważne źródło inspiracji). Takie imię nosi bowiem muzułmańska wybranka głównego bohatera utworu — zakonnika, Araba, który niegdyś wyrzekł się islamu i przyjął chrzest. Dokonując konwersji na chrześcijaństwo, a następnie wstępując do klasztoru, musiał rozstać się ze swą młodzieńczą miłością. Zachował jednak podarowane przez nią amulety z wersetami Koranu. Widmo Zary, skłaniającej umierającego „mnicha” do powrotu do religii ojców (powrotu warunkującego złączenie się z ukochaną w muzułmańskim raju), jest powodem dramatycznej duchowej walki, jaką bohater Słowackiego toczy w ostatnich chwilach swego życia.

Literacka kariera tego orientalnego imienia kobiecego na Zachodzie rozpoczęła się prawdopodobnie w 1697 r., kiedy angielski pisarz William Congreve nadał je bohaterce swej sztuki The Mourning Bride, niezwykle popularnej w tamtym czasie (zob. http://talebooks.com/ebooks/557. pdf) (dostęp: 6.11.2016). Jego Zara była piękną moryską królową, porwaną do niewoli przez władcę Granady, Manuela. Kolejny krok należał do zafascynowanego Orientem Voltaire'a: ten obdarzył imieniem Zara tytułową bohaterkę swej tragedii, rozgrywającej się w Jerozolimie w czasach wypraw krzyżowych (Zaïre, wyst. w Comédie-Française w 1732 r.). Zara Voltaire’a była jednak chrześcijanką, porwaną i wychowaną w duchu islamu. Została zasztyletowana przez szaleńczo zakochanego w niej, zazdrosnego sułtana Osmana (widziano w nim drugiego Othella, w Zarze zaś odpowiednik szekspirowskiej Desdemony). Voltaire zawdzięczał swój pomysł Szekspirowi, ten zaś zaczerpnął inspirację z renesansowego włoskiego zbioru nowel (Hecatommithi) autorstwa Giovanniego Battisty Giraldiego (Cinzio). Jego opowieść o Disdemonie, niesłusznie oskarżonej przez swego męża Maura o zdradę, była przestrogą przed zawieraniem małżeństw z mężczyznami wywodzącymi się z innych kultur.

Zaïre Voltaire'a została szybko przełożona na język angielski przez Aarona Hilla (Zara: A Tragedy) i stała się najczęściej wystawianą w Anglii sztuka wolteriańską. Zainspirowała ona autorów aż trzynastu dzieł operowych (m.in. Vincenzo Belliniego w 1829 r.) To one rozsławiły imię Zara w całej osiemnasto- i dzięwiętnastowiecznej Europie i sprawiły, że najchętniej nadawano je arabskim bądź perskim pięknościom z opowieści stylizowanych na wschodnie. Sygnalizowało ono zarazem wysokie, szlachetne (często książece lub królewskie) pochodzenie bohaterek.

Góry, Literatura, Kultura 11, 2018

(C) for this edition by CNS 
A mnie tak smutno. — Gdzież jesteś o Zaro!

Najlepszy ziemi tej kwiecie,

W mym własnym sercu wypieszczona maro,

Jedyne rojeń mych dziecię?

(Nad Arakwa, Ananu 1842)

Obok modlitwy miłość staje się jedyną dostępną formą transgresji; tylko ona pozwala przekroczyć granice zesłańczego piekła:

O Nizzo! Tatarii pustyń ozdobo!

Pokochaj mię duszą, a pójdę za tobą,

Za tobą przez dzikie rozdoły Szyrwanu

Przez góry Kaukazu, przez mgły oceanu.

Na stepach znajdziemy nieznaną od ludzi

Oazę, co ciągle wydycha woń kwiatów;

Tam wietrzyk łagodny znój lata ostudzi,

Pragnienie utuli sok winny granatów.

Są wyspy na morzach, jaskinie na górach!...

Swobodni, jak orły kąpiące się w chmurach,

Zapomnim wzajemnie

- ty o swym aule,

A ja o Europie gdziem cierpiał i marzył,

Niesyci rozkoszy co los nam nadarzył,

Będziemy się kochać namiętnie i czule...

I wtenczas o Nizzo! przez życia odmęty

Popłyniesz przede mną jak Raju posłanka,

I szczęścia cichego rozścielesz blask święty

$\mathrm{Na}$ ścieżkę twojego ziemskiego kochanka.

(Do Nizzy)

W tej orientalnej poezji rozkoszy dokonuje się specyficzna kontaminacja dwóch erotycznych wyobrażeń: góralka-córa natury staje się tajemniczą (muzułmańską) kusicielką. Wydaje się, że takiego odważnego połączenia nurt polskiej literatury „górskiej” nie będzie znał przynajmniej do czasów prowokacji młodopolskich:

Piękna Góralko! przystałoż tobie,

W twojego życia najrańszym maju,

Dumać i marzyć o zimnym grobie,

O Mahomeda rozkosznym raju?

Raj twój na ziemi! piękna Góralko!

O! świeć mi w ciemni życia bezbrzeżnej,

Jak nad potopem mąconym walką

Wściekłych żywiołów gołąbek śnieżny. 
Przynieś oliwną różdżkę pogody

W korab mój ciągłą miotany burzą:

A wnet opadną wezbrane wody,

A wnet się groźne nieba przechmurzą.

Jak Kajszauru róża ponętna

Napawa tchnieniem Arakwy tonie,

Tak i ty na mnie, Góralko smętna!

Wyzioniesz słodkie młodości wonie. [...]

Pamięć o tobie, jak nitka złota

Wplątana w czarne pasmo osnowy,

Zalśni we mroku mego żywota

Rzucając w koło oblask tęczowy.

(Do góralki Lars, 21 maja 1842)

Zakaukaskie rojenia miłosne Zabłockiego przywodzą niekiedy na myśl Mickiewiczowskie wersy o niespełnionej sielance miłosnej w górach — „Ach! Ja bym cię za rękę po tych skałach wodził" (Do *** Na Alpach w Splügen):

O jakże śliczna noc wiosenna w górach!

Jakże rozkoszne jej chłody!

Jaśniejsze gwiazdy zda się tlą w lazurach,

Dźwięczniejsze pienią się wody. [...]

Przyjdź, czarodziejko! ach prędzej przyjdź tutaj,

Gdy dusza pragnie podziału,

Pod cieniem nocy blask piękności utaj

I weź hołd mego zapału.

Ja cię po górach oprowadzę śnieżnych,

I z najwyższego ich szczytu,

Ukażę ć' stronę śród równin bezbrzeżnych,

Przedmiot twojego zachwytu.

(Nad Arakwa, Ananu 1842)

W innym kaukaskim wierszu wschodnia piękność z marzeń wygnańca obdarzona została innym znaczącym imieniem, zaczerpniętym z mitologii irańskiej (a także armeńskiej ${ }^{55}$ ): Peri (staropers. parikā-, średniopers. parīg, pers. parī).

55 Imię to pojawia się też w mitologii armeńskiej: irańska Parīg staje się armeńską parik. Pari obecna jest też w folklorze ludów gór Hindukusz (Pakistan-Afganistan) jako paris, baris bądź bar ais. Określenie to zostało odniesione w kulturach Wschodu również do tancerki — zob. S. Adhami, Pairikā, [w:] Encyclopaedia iranica, http://www.iranicaonline.org/articles/pairika (dostęp: 27.03.2017). 
Te skrzydlate istoty, zajmujące pośrednią pozycję w hierarchii duchów dobrych i złych, znane są już z ksiąg Awesty (pairik $\bar{a}-$ ), tekstu Wedy i z literatury manichejskiej ${ }^{56}$. W młodszej literaturze perskiej (m.in. w eposach Szahname Ferdousiego i Sāmnāma Kwajo-ye Kermanī) parī tracą wszelkie negatywne konotacje i stają się dobrymi wróżkami, nimfami, rodzajem dobrych dżinów (przeciwieństwem złych diwów), obdarzonych pociągającym wyglądem i zdolnych rozkochiwać w sobie mężczyzn (rdzeń parī- odnaleźć można do dziś w wielu żeńskich imionach perskich); wykazują zatem wiele cech wspólnych ze słowiańskimi rusałkami ${ }^{57}$. Imię Pari (i Parizada) odnaleźć można także w księdze Tysiąca i jednej nocy, w jednej z finalnych opowieści Szeherezady ${ }^{58}$.

W literaturze europejskiej nazwa „Pari” została zmodyfikowana do „Peri”. Imię to rozpowszechnił na Zachodzie oczarowany perskim Orientem Thomas Moore $^{59}$ w poemacie Lalla Rookh $(1817)^{60}$. Jego fragment - Paradise and the Peri (Raj i Peri) — został przełożony na język polski w latach czterdziestych XIX w. przez Antoniego Edwarda Odyńca (wyd. w 1843 r.) ${ }^{61}$. Autor tego przekładu objaśnił, że

Peri, w mitologii wschodniej, są to duchy dobre, stopniem tylko niższe od aniołów, chociaż równej piękności. Niegdyś wygnane z Raju, mieszkające na powietrzu, w wodzie i w najpiękniejszych okolicach na ziemi: w zaczarowanych napowietrznych ogrodach lub w kryształowych na dnie morskim pałacach. Żyją wonią kwiatów i rosą ${ }^{62}$.

Imię „Peri” zrobiło wielką karierę również w Polsce; Adam Mickiewicz obdarzał nim czule Marylę Wereszczakównę w swej filomackiej korespondencji z Tomaszem Zanem, a Juliusz Słowacki porównywał do Peri bohaterkę swej

56 Zob. ibidem.

57 Zob. ibidem.

58 Zob. ibidem.

59 Wcześniej peri pojawia się w orientalnej powieści gotyckiej Williama Thomasa Beckforda (1782) Vathek.

60 Zob. T. Moore, Paradise and the Peri, [w:] idem, Lalla Rookh, http://www.bartleby.com/ library/poem/3665.html (dostęp: 27.03.2017). Utwór Moore'a stał się inspiracją dla Roberta Schumanna, który w 1843 r. skomponował oratorium pt. Das Paradies und die Peri (op. 50).

61 Zob. T. Moore, Peri i raj, przeł. A.E. Odyniec, [w:] Tłumaczenia Antoniego Odyńca, t. 5, Wilno 1843, s. 54, http://dlibra.ujk.edu.pl/dlibra/docmetadata?id=239\&from=publication (dostęp: 27.03.2017). Główna bohaterka poematu, Peri, pragnąca powrócić do Raju, wzruszyła swymi łzami Anioła strzegącego wejścia do Edenu. Objaśnił on Peri, że otworzy przed nią bramy Edenu tylko, jeśli znajdzie ona i przyniesie dar godny niebios. Ani męczeńska krew wylana za ojczyznę, ani „,westchnienie czystej i samo ofiarnej miłości” umierających kochanków nie zdołały jednak otworzyć rajskich bram. Uczyniły to dopiero łzy skruszonego grzesznika, nawróconego na widok pokornej modlitwy dziecka. Poemat Moore’a pełen jest zachwytów nad pięknem wschodnich krain: Tybetu, Indii, Egiptu, Libanu, Syrii (zwanej tu Suristanem, czyli Krajem Róż), Palestyny.

62 Ibidem, s. 55. 
powieści poetyckiej Lambro (1833). O peri- ,aniołach w Raju Mahometa” pisał także Ludwik Spitznagel w swym wierszu Do Konstantego Rdułtowskiego, zamierzając z nim podróż na Wschód. ${ }^{63}$. Zabłocki wpisywał się zatem już w pewną onomastyczną tradycję i kulturę erotyczną romantyzmu, naznaczoną orientalnymi skojarzeniami.

Podobnie jak w poemacie Moore’a, także w poezji Zabłockiego Peri — eteryczna, skrzydlata istota (upadły anioł) — jest nie tylko uosobieniem piękna i subtelności, lecz także dobrym duchem przyjaznym ludziom, szczerze litującym się nad ich niedolą:

O córo wschodniej krainy

Jedna ty z ludzi natłoku,

Pytasz się smutku przyczyny

$\mathrm{Z}$ westchnieniem, ze łzą w oku!...

Spójrzyj na góry Kaukazu,

Jakiż to ogrom niezmierny!...

Ach! za granicą tą z głazu

Świat się rozwija obszerny.

I tam niebiosa jaśnieją,

I tam kobierce łąk kwitną,

I bystre rzeki się leją

Wstęgą promienno-błękitną.

I tam są piękne dziewice,

Jak wasze Peri ponętne,

Co mogą rzucić w tęsknice,

Albo w marzenia namiętne.

(Do Zary, Carskie-Kołodce 10 lipca 1838)

Czyniąc Kaukaz miejscem zamieszkania pięknej i dobrej Peri, Zabłocki automatycznie włączył tę górską przestrzeń do elitarnego grona najpiękniejszych

63 „Ostatni raz widząc się z Peri — czytamy w liście Mickiewicza do Zana — powiedziałem jej kilka przykrych rzeczy umyślnie, aby ją zasmucić. Po dłuższym rozmyśle czuję nikczemność mego postępowania. Nie spojrzała na mnie, kiedym wyjeżdżał”. Adam Mickiewicz do Tomasza Zana, Kowno, 16/28 października 1822, [w:] Korespondencja filomatów. Wybór, oprac. Z. Sudolski, Wrocław-Warszawa-Kraków 1999, s. 163.

Podobnie zwracał się do tej samej adresatki Tomasz Zan: „Tak byłem zmartwiony doniesieniem o smutku i cierpieniach Peri, że nie tylko przyjemnym być przestałem, ale nawet w myślach moich i piórze nie mogłem odkryć ani szczypty przyjemności, którą bym niniejszy rozdziałek posolił" - Tomasz Zan do Marii z Wereszczaków Puttkamerowej, Wilno, 19 września/1 października 1822, [w:] Korespondencja filomatów..., s. 154. 
ziemskich krain i ogrodów, ustępujących wdziękiem jedynie Edenowi ${ }^{64}$. Kaukaskie góralki zyskały zaś status istot niemal anielskich, z pogranicza jawy i rozmarzonej poetyckiej wyobraźni.

Ważnym działem orientalnego dorobku Zabłockiego są też jego translacje z języków wschodnich, którym pobyt na Kaukazie szczególnie sprzyjał. W Poezjach z 1845 r. zaprezentowana została tylko ich nikła część, poza zbiorem pozostały na przykład przekłady twórczości azerbejdżańskiej oraz pieśni tatarskich. W tomie znalazł się natomiast przekład fragmentu II sury Koranu, zapewne z języka francuskiego. Adnotacja do Lezginki przywołuje tłumaczenie sporządzone przez osiemnastowiecznego orientalistę francuskiego, pioniera egiptologii - Claude'a-Étienne’a Savary'ego (1750-1788) ${ }^{65}$, być może to właśnie ono znajdowało się w posiadaniu Zabłockiego i było przedmiotem tłumaczenia.

Czyż pamiętacie o tem należycie

Gdy wiódł król pewny z Abrahamem sprzeczkę,

Mój Bóg, rzekł prorok, daje śmierć i życie,

I w utrapieniach bezpieczną ucieczkę.

I ja, zuchwały głupiec odrzekł dumnie, Mogę śmierć roznieść, albo życie nadać;

I ja, jak Bóg twój, mądrze i rozumnie

Ogromem świata potrafiłbym władać.

Lecz Bóg mój, z gniewem odparł starzec święty.

Codziennie słońce wytacza ze Wschodu,

Jeśli’ś mu równy, grzeszniku przeklęty!

Choć raz tę gwiazdę cofnij wstecz z zachodu

I zamilkł wstydem płonący bluźnierca !...

Bóg nie oświeca pokalane serca

(Sprzeczka z Al Koranu. Rozdział 2 pod tytułem:

Krowa)

${ }^{64} \mathrm{Z}$ listu Zabłockiego do J.I. Kraszewskiego z 30 lipca 1840 r. wynika, że poeta przesłał wiersz o orientalnie pobrzmiewającym tytule Prośba Proroka (zob. M. Filina, D. Ossowska, op. cit., s. 246), jednak jako jedyny z nadesłanych nie znalazł się on pośród poezji Zabłockiego zamieszczonych przez Kraszewskiego w „Atheneum”. Treść tego utworu pozostaje zatem, niestety, nieznana (zob. „Atheneum" 1846, nr 6, s. 106-116, http://www.wbc.poznan.pl/dlibra/applet?mimetype=image/x.djvu\&se$\mathrm{c}=$ false\&handler=djvu_html5\&content_url=/Content/402465/index.djvu (dostęp: 27.03.2017).

65 Zob. Le Coran, traduit de l'arabe, accompagné de notes, et précédé d'un abrégé de la vie de Mahomet, tiré des écrivains orientaux les plus estimés, Paris-Amsterdam-Leyde 1782-1783. Autor ten wydał również Morale de Mahomet, ou Recueil des plus pures maxims du Coran, Paris 1784 (http://www.lenoblecoran.fr/wp-content/uploads/Le-Coran-Traduction-de-C-E-Savary-Volume-1. pdf, dostęp: 27.03.2017) i wiele innych cennych dzieł o tematyce orientalnej. 
Tłumaczył też Zabłocki poezję gruzińską; jeden z tych przekładów został zamieszczony w petersburskiej edycji z 1845 r.:

Mikwars pïała brólisa

Bos nabierckali hwynisa it. $d$.

Lubię czarę kryształową

Gdy w niej wino szumi, pryska:

Kiedy falą purpurową

Bieży, płonie, iskry ciska.

Lubię usta cór Kaukazu

Miłosnego pełne trunku,

Gdy roztopią się od razu

$\mathrm{W}$ rozognionym pocałunku.

Lecz na usta baby stare

Z których spłynął szkarłat życia,

Patrzę z wstrętem jak na czarę,

Próżną, wyszłą już z użycia.

(Czara, z gruzyjskiego)

W 1849 r. pismo wileńskie „Rubon” opublikowało jego tłumaczenia Kilku pieśni gminnych zakaukaskich Tatarów. Dokonał ich Zabłocki z pomocą azerbejdżańskiego historyka Abbasa-Kuli-Agi Bakichanowa, którego dzieło Historia wschodniej części Kraju Zakaukaskiego (nieopublikowane) sam był przymuszony ex officio przekładać — bez żadnej chwały i profitu — z perskiego na rosyjski (myślał też o przełożeniu go na polski ${ }^{66}$ ). Jednym z owych przyswojonych polszczyźnie tatarskich tekstów jest popularna i lubiana w Szyrwanie ludowa piosenka zatytułowana Ona:

Jam go ujrzała stojącego pod basztą,

W błękitnej koszuli i czerwonym kaftanie.

Ogadujcie mię, ludzie, jeżeli chcecie,

Bom go ukochała na wieki.

Nie ciskaj we mnie kamieniem, Jestem i bez tego zraniona. [...]

Kto się raz nie oparł miłości, ten się zakochał na wieki. [...]

Śnieżne góry Erywanu oddzieliły nas obecnie.

Dziewczęta z Gruzji z łatwością

${ }^{66}$ Zob. T. Łada-Zabłocki, List do J.I. Kraszewskiego z 15 II 1843 roku, [w:] M. Filina, D. Ossowska, op. cit., s. 243-244. Por. także M. Janion, op. cit., s. 347. 
Znęcają i okradają serca.

Nie wiem, co się tam stanie z moim kochankiem.

Nie ciskaj na mnie kamieniem,

Jestem i bez tego zraniona

Cały lud odziany w szaty godowe,

Ja jedna chodzę w żałobie.

Mówią, że tam zaszła krwawa bitwa.

Mówią, że wróg zdradziecki okrążył i wymordował część Sarbazów.

Ach, oczy moje błąkają się po drodze,

A język szepce modlitwę.

Nie ciskaj we mnie kamieniem,

Jestem i bez tego zraniona. [... $]^{67}$

Wacław Kubacki nazwał tę poruszającą kaukaską pieśń miłosną „ludowym wariantem Pieśni nad pieśniami”:

Piosenka zakochanej dziewczyny („zranionej” w języku wschodniej poezji), która żyje w trwodze o wybrańca, to jakby ludowy wariant Pieśni nad pieśniami. Cztery zwrotki malują niepokój ducha — skróty sytuacyjne, przeskoki myśli, luźne skojarzenia obrazowe. A cztery refreny ciasno oplątują bohaterkę jak więzy dręczących przypomnień. Azerbejdżańska Sulamitka dorównuje swej biblijnej siostrze w wyrazie uczuć. Przewyższa ją prostotą. Sceną jej miłości nie jest mistyczna winnica, przypałacowy ogród ni zbytkowna komnata w królewskim haremie. Ona żyje, kocha, tęskni i rozpacza w kraju, gdzie płoną chaty, cieknie krew mężczyzn i płyną łzy kobiet. Jej żałoba wplata się politycznym wątkiem do miłosnej sielanki. Był to niewątpliwie motyw bliski tłumaczowi, którego wywieziono na Kaukaz z ziemi, na której młode dziewczęta po stracie braci i narzeczonych przywdziewały na resztę życia „czarną sukienkę"68.

Choć zachował się ledwie ułamek wschodnich przekładów Zabłockiego, nie zmienia to faktu, że wartość jego pracy — często pionierskiej — była ogromna. Tłumaczenia i przeróbki prezentowały Kaukaz prawdziwy, odbity w lustrze świadomości mieszkańców Wschodu. Pozwalały one polskim czytelnikom poznać ten odległy region i, co ważniejsze, niemal dotknąć kaukaskiej duszy.

Swobodne poruszanie się w etnograficznej materii Kaukazu, liczne kontakty z twórcami gruzińskimi i azerbejdżańskimi czyniły Zabłockiego poetą znanym

67 Ona, [w:] Kilku pieśni gminnych zakaukaskich Tatarów, przeł. T. Łada-Zabłocki, „Rubon” 10, 1849, s. 105-111.

${ }^{68}$ W. Kubacki, op. cit., s. 67-68. 
tbiliskiej inteligencji i powszechnie cenionym. Nic dziwnego, że w gronie prenumeratorów jego petersburskich Poezji znaleźli się Gruzini, Tatarzy i Lezgini. W tych polskojęzycznych tomikach znajdowali wszak echo własnej kultury i historii, kaukaską przyrodę i ludowe pieśni podniesione do rangi sztuki.

W marcu 1844 r. poeta otrzymał awans na chorążego (praporszczika). Ten najniższy stopień oficerski dawał mu prawo do uzyskania dymisji z armii carskiej po niemal ośmiu latach niebezpiecznej i wyniszczającej służby (18371844). Rozważał wówczas różne warianty swej przyszłości, w tym powrót do kraju, ale snuł też ambitne plany podróżnicze. Nieodległy z Kaukazu Orient perski pociągał go bowiem od dawna. Już w 1840 r. pisał z Tyflisu do Kraszewskiego: „zupełne osłabienie mojego zdrowia potrzebującego ciepłego powietrza wschodu i tutejszych wód mineralnych, może zmuszą mnie na zawsze pozostać w Georgii, lub nawet posuną bliżej ku południowi, w prowincje wcielone do Persji [...]"69. Odzyskanie swobody sprawiło, że zamiary udania się do „Persji, Azji Mniejszej, Arabii, Nubii i Palestyny"70 odżyły, jednak ze względów finansowych spełzły na niczym. Jeszcze jedno z wielu polskich orientalnych marzeń legło w gruzach, bez wątpienia z wielką stratą dla narodowej literatury i kultury.

Złudzeniem okazała się także inna przedśmiertna fantazja Zabłockiego: jego utopijne nadzieje, że pod namiestniczymi rządami wicekróla Kaukazu, wychowanego w Wenecji i w Anglii liberalnego (przynajmniej jak na standardy rosyjskiego aparatu urzędniczego) księcia Michaiła Woroncowa (notabene żonatego z Polką, Elżbietą z Branickich), kraina ta zacznie „tracić cechy azjatyzmu” i „stanie się Włochami Rosji”"71. W tym marzeniu o przywróceniu Kaukazu do stanu mitycznej harmonii zawarte było zarazem pragnienie zniwelowania etycznej przepaści, jaka oddzielała polskich zesłańców od ich ojczyzny i całego cywilizowanego świata ${ }^{72}$. Limes, której bliskie zniesienie radośnie obwieszczał Kraszewskiemu Zabłocki, była przede wszystkim granicą respektowania ludzkiej

69 T. Łada-Zabłocki, List do J.I. Kraszewskiego z 16 XI 1840 roku, s. 229.

70 T. Łada-Zabłocki, List do J.I. Kraszewskiego z 30 VII 1846 roku, [w:] M. Filina, D. Ossowska, op. cit., s. 245.

71 T. Łada-Zabłocki, List do J.I. Kraszewskiego z 8 V 1847 roku, [w:] M. Filina, D. Ossowska, op. cit., s. 248. Woroncow sprawował funkcję namiestnika cara na Kaukazie do 1854 r.

${ }^{72}$ Nie miał natomiast złudzeń co do prawdziwych intencji polityki Woroncowa inny zesłaniec, Mateusz Gralewski, który w swych kaukaskich wspomnieniach niezwykle surowo ocenił wyrachowane działania tego rosyjskiego namiestnika Kaukazu: „Wielu było rządców w Gruzji od czasu upadku tego kraju, którzy zręcznie podkopywali korzenie jego narodowego bytu. [...] ale żaden z nich nie zaszkodził Gruzji tyle, ile książę Woroncow. Ten przebiegły polityk nie wysyłał Gruzinów ani na Syberię, ani gdzie indziej. Owszem, jawił się on ich najgorliwszym przyjacielem. [...] trzymał się [...] systemu rujnującego względem wyższej warstwy społeczeństwa. [...] balami, ubiorami i wystawnością wschodnią zniszczył Woroncow zasoby panów gruzińskich. [...] Rujnując bogactwo narodowe, namiestnik widocznie propagował gry w karty i rozprężenie obyczajów. Roznieceniem słabych namiętności starał się odwrócić uwagę panów od swoich działań i zabijać w nich wszelkie uczucia patriotyczne. Ten piekielny system wszystkich zaborczych i despotycznych rządów doskonale mu się udawał" — idem, op. cit., s. 409. 
wolności i godności. Zamiana kojarzącego się Polakom z carskim despotyzmem „azjackiego” „Wschodu” na kojące orientalne „Południe” nie urzeczywistniła się. Jedynie zesłańcza poezja Zabłockiego przekroczyła ustanowioną przez rosyjskie imperium, a opartą o łańcuch Kaukazu, barierę dwóch światów (choć i ona nie bez szwanku) - jej utalentowany twórca pozostał za „granicą z głazu” już na zawsze. 